Tales of tricks and greed and big surprises: Laymen's views of the law in Dutch oral narrative

THEO MEDER

Abstract

Neither in Dutch nor in European narrative folklore does the lawyer have a positive reputation. It does not matter whether we look at the past or the present: in folktales the practice of lawyers is associated with greed, trickery and heartlessness. In the Middle Ages, when the profession was literally for sale, judges were accused of corruption and incompetence, but their reputation improved over time when they became well-educated and impartial professionals. In present and past, the common man looks upon justice as incomprehensible and unpredictable. European and American folktales (especially jokes) about law and lawyers basically share the same themes, but there is a remarkable difference in quantity nowadays. Whereas lawyer jokes are hype in the U.S they are not in the Netherlands or Western Europe. The main reason seems to be the American "vulture culture" of suing claiming, and cashing, as exposed in the news media. If Dutch and Euro pean lawyers take over the mores of their American colleagues, it will just be a matter of time before a vast number of lawyer jokes are transferred and translated.

Keywords: Folktales; folklore; lawyer jokes; legends.

The trouble with lawyer jokes is: Lawyers don't think they are funny and laypeople don't think they are jokes. 


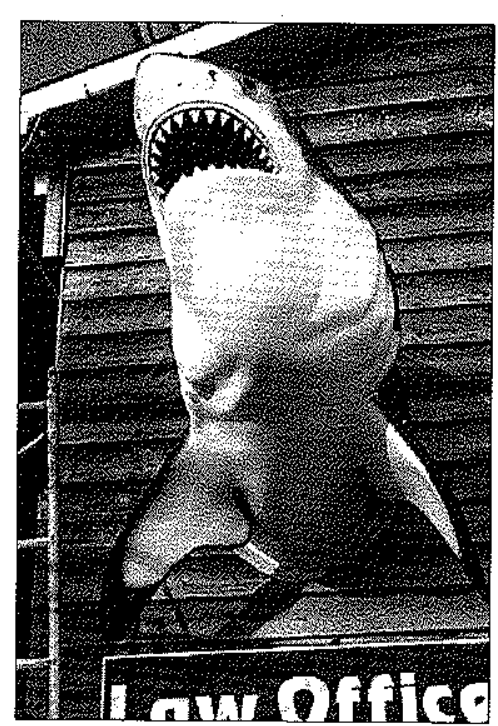

Figure 1. The shark as a personification of the American lawyer

\section{Popular narrative}

In this article, I would like to focus on some Dutch (and other European) folktales concerning law, judges, and lawyers. I will argue that, in comparison with older stories, the reputation of judges is relatively good nowadays, whereas the negative reputation of lawyers has not improved much since the Middle Ages. On the other hand, this negative image of lawyers has not led to a huge number of contemporary lawyer jokes in the Netherlands as it did in the United States.

I will be looking at folktales, i.e. popular, international, and (mostly) orally transmitted narratives, varying from traditional genres like fairy tales, fables, and legends to modern genres like jokes, funny riddles and urban legends. We are mainly dealing with fiction (though various kinds of stories are thought to be true by many), and I must also stress that folktales cannot be considered a mirror image of reality. Folktales have to be considered as bearers of mentalities. Folktales always form a subjective representation of how "ordinary folk" perceive reality. Folktales are all about perception - not necessarily about how life is, but about how people feel and believe it is. Folktales reflect the latent values, preoccupations, anxieties, taboos, prejudices, and desires of narrators and their audiences. For this reason, narrative culture can serve as an instrument for cultural diagnosis. Popular narrative is a sensitive barometer for collective moods in society (Meder and Venbrux 2000)

Consequently, folktales about judges and lawyers can be interpreted as the outsiders' view on the practice of law in a given society at a certain time. The majority of folktales on legal practices are not invented nor actively spread by the in-group (although eventually, the in-group may join in, as a kind of defense mechanism). Most of these tales are made up by anonymous representatives of the out-group, in no way hampered by any solid legal knowledge. By means of storytelling, laymen and outsiders air their views and opinions of the administration of justice. Often these folktales are told from an underdog perspective; they are told by ordinary people who stand on the "powerless side" of the law (and I do not just mean criminals)

In order to give an impression of the themes involved, I would like to present five Dutch (and European) examples of folktales from the past and the present. ${ }^{1}$

\section{The ungrateful serpent returned to captivity}

The first example is a widespread fable, known as ATU 155, The Ungrateful Snake Returned to Captivity, in the international catalogue of folktales by Antti Aarne, Stith Thompson, and Hans-Jörg Uther (Uther 2004; see also Meder 1997). The tale has been found in Europe, Asia, Africa, and North and South America. The oldest Dutch version of this fable dates back to 1400 A.D., the most recent versions have been recorded from oral tradition in the 1970s. The version I will discuss here was written around 1400 by the Dutch "sprookspreker," Willem van Hildegaersberch ( $\pm 1350-1408)$, who entertained the aristocracy, the clergy, and the bourgeoisie of the medieval Low Countries as a professional performing poet (Meder 1991). The title of his poem is "Van den serpent" About the dragon (Bisschop and Verwijs 1870: 53-56). In a nutshell, this is how the story goes:

One day a travelling knight finds a dragon with his claws caught in a split tree. Out of compassion the knight liberates the captivated - and seemingly meek dragon, but as soon as he does so, the malicious dragon injures the knight with his venomous breath. 
"Is this your way of showing gratitnde?" the knight asks.

"It's the way of the world," the dragon replies: "Good gets rewarded with evil every day."

Since the knight keeps on protesting, the dragon suggests taking the case to trial It is agreed upon to ask the first animals they encounter for a verdict.

Unfortunately, these animals happen to be the sheep and the goose. Being ignorant prey, they can hardly distinguish between right and wrong, so their verdict is that the dragon is right

(The poet remarks that the sheep and the goose can be compared to the incompetent sheriffs of his time. He adds that for their verdict the sheep and the geese are rightfully shaven and plucked.)

While the knight is still making or

making objections, Reinaert the Fox walks by. It is soon agreed that the smart fox will pass sentence.

"Listen, I cannot decide in this case, unless we have a reconstruction of the incident," Reinaert says.

So the dragon sucks his poison out of the knight and sticks his claws into the split tree again.

"Now that we have restored the initial situation," Reinaert says, "here is my verdict: let's leave things as they were." The knight agrees, and the man and the fox go their way, leaving the ungrateful dragon in captivity again.

Although Willem van Hildegaersberch added some details of his own, this is how the plot goes in most of the versions of ATU 155. In the end, justice is done, but do not ask how! The case is won by the knight, not by appealing to the (incompetent) sheriffs, not by applying the law, but through the wit of an outlaw trickster. As the poet literally says, "Ic woudment noch soe verre brochte / Datmen schalck mit schalken vinghe" (v.v. 190191) he more or less means: it takes a crook to catch a crook. From a legal point of view, justice failed, but from a moral point of view justice prevailed. Justice was done by trickery, not by applying the law.

According to both the poems of Willem van Hildegaersberch and the work of other medieval poets, much is wrong with the legal system and its practice. In addition to the incompetence of judges, greed, bribery, and corruption are also frequently mentioned. Furthermore, there are some obvious cases of "class justice," i.e. a poor man can hardly ever win against a rich man or a nobleman, no matter how just his case may be (cf. Pleister 1988: 183-186).

\section{The greater bribe}

The corruption of judges in the past could well be illustrated with another poem by Willem van Hildegaersberch, entitled About the Wagon

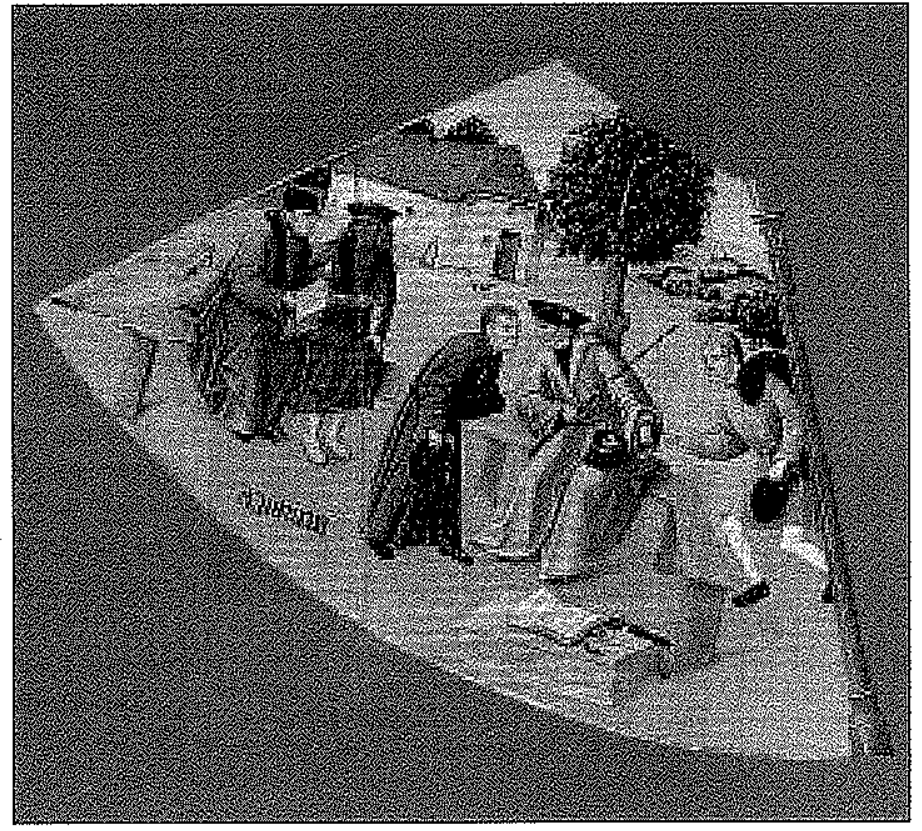

Figure 2. Avaricia: the corrupt judge. Detail from The Seven Deadly Sins (ca. 1485) by Hieronymus Bosch (1450-1516)

("Vanden waghen"; Bisschop and Verwijs 1870: 36-39). This story is internationally known as ATU 1861A, The Greater Bribe, (orally) transmitted over the entire Eurasian continent, and known in Jewish and Arab traditions as well (Uther 2004; Tubach 1969: nrs. 453, 2851, 2998; Vries 1928: 253). In the version told by Willem, a carpenter and a butcher fight over a legacy in court. As soon as the carpenter presents the judge's wife with a wagon, the judge is on the carpenter's side. The butcher decides to give the judge's wife four oxen. Now the verdict turns out to be in favor of the butcher. In an attempt to make the judge reconsider the verdict, the carpenter calls out: "Turn the wagon." Whereupon the judge answers, "The wagon cannot be turned, for the oxen want to go the other way."

Willem van Hildegaersberch uses this story as an exemplum of corruption (and class justice) in daily life. He strongly opposes the fact that money and power prevail over righteousness. Willem warns the judges that they themselves will once stand trial before the highest Judge.

In the Middle Ages, when the profession was literally for sale, judges were accused of corruption and incompetence, but in the Netherlands 


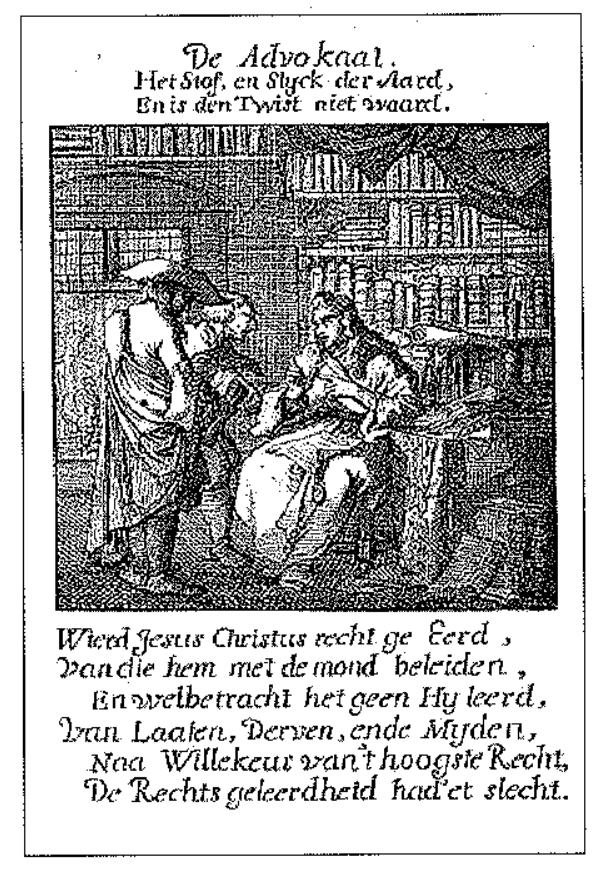

Figure 3. Portrayal of the lawyer by Jan Luycken (1649-1712). The message of the verses is: we do not need lawyers if we all live like God-fearing Christians

their reputation improved over time when they became well-educated and impartial professionals. If I am not mistaken, the turning point can be situated somewhere between the late Middle Ages and the Dutch Golden Age (seventeenth century)

\section{The lawyer's mad client}

The third example is another anecdote or joke. Again this is an international folktale, which has been orally transmitted for centuries and is catalogued as ATU 1585, The Lawyer's Mad Client (Uther 2004; Marzolph 2001). This time, I will be quoting a recent version, as told by the Frisian working class narrator Hendrik Meijer on April 3rd $1969 .{ }^{2}$

There once was a farmer who had stolen four sheep. The police found out, the sheep were confiscated, and the farmer had to stand trial.

He went to a lawyer and said to him: "I was caught stealing four sheep. I will have to stand trial. Will you defend me?"
"Alright," the lawyer said, "I will defend you. But it will cost you 300 guilders." [Which was a lot of money in those days, TM]

"That's fine by me," the farmer replied.

"Well," the lawyer continued, "when you have to appear in court, you must pretend to be crazy. When the judge asks you a question, you must say: 'Bal'"

"Okay," the farmer said.

He went to court and the judge asked him a question.

"Baa!" the farmer replied.

The judge asked him another question.

"Baa!" the farmer said.

And the third time, again, he said, "Baa!"

And the third time, again, he said, "Baa!" As the farmer walked out of the courthouse, the lawyer was already waiting for

"I would like to have my 300 guilders now," the lawyer said.

"Baa!" the farmer said.

"You fool," the lawyer said, "you don't have to do that anymore."

"Baa!" said the farmer. He said "baa!" to everything, and the lawyer did no know what to do.

He never got his 300 guilders.

In the first story, an unlawful trick was used to punish the guilty party. In this third story, a lawyer misuses the law to free his guilty client. Still, we are inclined to sympathize with the farmer, because he plays the same trick on the greedy lawyer.

\section{The devil and the lawyer}

The fourth story is internationally catalogued as ATU 1186, The Devil and the Lawyer. The tale has mainly been told in Europe, and the oldest known versions date back to the thirteenth century (Uther 2004; Röhrich 1977; Van der Kooi 1997). ${ }^{3}$ It is a story about a lawyer and the devil meeting each other on a walk. As they walk along, they encounter several people: a butcher cursing a pig, a farmer cursing his horse, and a mother cursing her child. They all utter words like: "May the devil take you." Each time the devil is advised by the lawyer to actually take them, but the devil refuses to do so, because the curses were never sincere. Then they encounter a poor widow. She recognizes the lawyer who once had taken her last possessions away from her in a court of law. When she curses the lawyer to hell, he is immediately carried away by the devil. This time the curse was meant with the whole heart. 
In this tale, the poverty of the widow is not caused by the greed of the lawyer but rather by the fact that the lawyer showed no compassion whatsoever with the unfortunate woman in court. Although in many European versions it is a lawyer who goes to hell, it is a fact that in Dutch versions the lawyer is commonly substituted by a bailiff, who comes to collect arrears of rent at poor people's houses. ${ }^{4}$

\section{The microwaved pet}

The fifth and last example is not a traditional tale, but a modern narrative - a so-called urban legend to be more precise, in the Netherlands commonly known as a 'Broodje Aap-verhaal', a Monkey Burger Story. ${ }^{5}$ The story is internationally known under the title The Microwaved Pet (Brunvand 1994: 329). During the past twelve years, I came across twenty Dutch versions of this story. ${ }^{6}$

An elderly woman has a small poodle. Several times a day she takes the dog out for a little walk. Every now and again it rains, and the dog comes home wet. those cases, the woman preheats the hotair oven and puts the dog in for a sort while to let it dry. Unfortunately, one day the hot-air oven breaks down. The clenly wot it dry Unter day. After walking the dog a rainy day, she puts the small animal into the day. After walking the dog on a rainy day, she puts the small animal into the oven. Within a minute, the ind a happens: the hir of the dog catch and wham! The poodle explodes.

The elderly woman decides to sue the manufacturer of the microwave oven. After all, the manual never mentions that one is not supposed to put a live pet into the oven. The senior wins the lawsuit and receives a large sum of money as a financia compensation. Nowadays, all manuals for microwaves mention the impossibility to put a pet into the oven. Of course, this all happened in the United States.

Actually, it did not happen. Not in the United States, nor anywhere else Still, many people believe the story to be true-even legal students do. A Dutch law student once said:

It is such a well-known story, about the dog in the microwave. It's article 140 BW on product liability. The manufacturer has to pay the damages, because $h$ is liable. The judge decided that, in all fairness, this woman could not have known that it was impossible. I heard this so many times during lectures. There is a decree as well. It is something like the Leaking Hot-Water Bottle Decree, about children that had been burned by hot water from a hot-water bottle. (Burger 1993:
Is this law student right or wrong? One of the characteristics of an urban legend is that the plot is peculiar, but not unthinkable. Many urban legends are told with the reassurance that "It's true. It happened to a friend of a friend." This is why urban legends are also called FOAF-tales, in which FOAF stands for "Friend Of A Friend."

As far as folklorists have looked into the case of The Microwaved Pet, they never found the specific lawsuit. ${ }^{7}$ They did find people imitating the tale, but that is a different story

What does the story of The Microwaved Pet have to tell us? For one thing, it is a kind of humorous horror story. In a cruel way, we take pleasure in the death of the animal. We are dealing here with an appalling fluffy and trimmed little poodle, pampered like a child by her old mistress. The old woman cannot keep up with modern technology; she is too stupid to know that microwaves heat things up from the inside out. Anyone knows one cannot put a pet in a microwave oven without killing it, but not this old lady. So the pet dies; serves her right!

Then the second layer of the story is supposed to hit us by surprise. The lawsuit - at least in the layman's view - illustrates the complete unpredictability of jurisdiction. The outcome of the lawsuit is the opposite of what one would expect. The judge is actually rewarding the old lady for her stupidity. And what is more: in order to avoid enormous financial claims, manufacturers are forced to extend their manuals with the bleeding obvious. Whatever will be next? Do not put your bird into the aquarium, or it will drown? Do not swallow billiard balls, because you will suffocate? In other words, The Microwaved Pet story is a "tale of the unexpected." When told in the Netherlands, people often add that it all happened in the United States of America. For most listeners, this explains a lot. Lawsuits with strange outcomes are supposed to be quite common in the U.S. Somehow, it becomes less plausible when the story of The Microwaved Pet is told as if it had happened in the Netherlands. Apparently, most narrators and listeners do not find this story illustrative for the Dutch legal system.

\section{Legal themes and social context}

The five folktales I mentioned are highly exemplary for the themes involving justice in past and present. In summary, these themes are: 


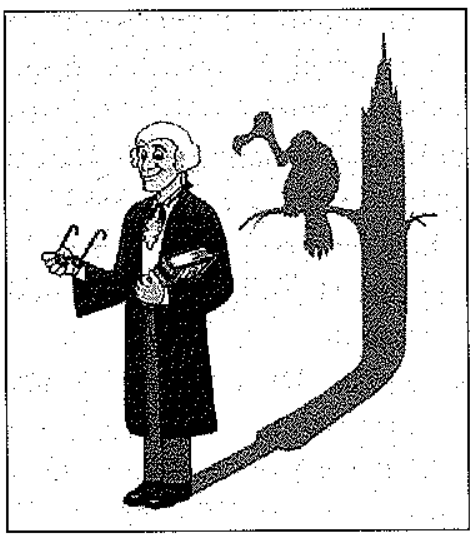

Figure 4. The traditional American lawyer as a vulture

Legal practice is characterized by greed (300 guilders for the advice to say "Baa!"), incompetence (goose and sheep), lack of compassion (the poor widow), and class justice and corruption (wagon and oxen) These are mainly themes of the past, with the exception of lack of compassion and greed - as a lot of contemporary lawyer jokes in the U.S. testify.

The results of lawsuits can be quite different than expected due to trickery ("Baa!'). Criminals go free, innocent people get convicted.

Jurisdiction is mysteriously incomprehensible: for outsiders the outcome of a lawsuit is often completely unpredictable, obscure, and puzzling. The reason behind this is that there is an obvious difference between being morally right and legally right (or morally wrong and legally wrong, for that matter). A legal case is not so much examined on the basis of a sense of right and wrong, but on the basis of written law (with all its man-made imperfections and interpretations). One of the most frustrating things throughout time, of course, is being morally right and legally wrong! Unfortunately being morally right is an extremely subjective concept.

Ordinary narration of folktales always involves tales of the extraordinary. inge of legal practice is seldom positive. ${ }^{8}$ Even in the famous and positive case of the righteous King Solomon, the king is relying on his wit rather than on the law. If a lawsuit results in a satisfactory solution, most of the time, unorthodox methods have been applied. If the outcome of a case is unfavorable, "ordinary folk" consider this to be a confirmation of the pessimistic image they already had of the legal practice.

Unlike the past, the image of judges today seems to be better than the reputation of the lawyers. In the Dutch narrative repertoires of the last centuries, the judges seem to be reliable and fair most of the time, and they even tend to show compassion with the "common man." In cases in which children have to stand trial, the righteous judge is able to distinguish between innocence and guilt. In a tale, internationally known as ATU 1343*, The Children Play at Hog-killing; one boy accidentally kills the other in a butcher's game. The judge lets the boy choose between a (golden) coin and an apple. The boy takes the apple, proving his childish innocence. In a similar tale, a gipsy girl is caught stealing. Again, the judge makes her choose between a coin and an apple. The girl takes the coin, proving to know the value of things and is convicted. ${ }^{9}$

The negative image of lawyers has not improved much over time, neither in the Netherlands, nor in the U.S. Today, lawyers' fees are out of proportion compared to the services supplied, especially in the U.S. The lawyers have a reputation for winning cases through tricks and legal hairsplitting. They try to delay justice by focusing on technicalities and legal procedures. When real criminals stand trial, the defense goes for discharge or minimal punishment, rather than for "not too much" or "fair enough" punishment. From the perspective of the laymen, it is not a pretty sight at all.

\section{Modern lawyer jokes}

However, if we take the actual number of Dutch tales and jokes about legal justice into consideration, it is not all that bad: in daily life, other themes appear to be more important than jurisdiction. When we look at jokes in the Netherlands, the topic of sex appears to be much more popular than law. After September 11, the assassination of politician Pim Fortuyn and filmmaker Theo van Gogh, a lot of jokes are being made about politics, ethnicity, Islam, and terrorism; these are issues of real concern, not the practice of lawyers. To my estimation, the number of lawyer jokes told in the Low Countries more or less equals the number of mother-in-law jokes. The number of folktales about jurisdiction is relatively small, and this goes for the present as well as for the past. 
For the Dutch Folktale Database at the Meertens Institute in Amsterdam, I have so far collected no less than 34,000 folktales, including jokes and funny riddles. Between 1994 and 2006, only five Dutch jokes entered the Database, which can be qualified as lawyer jokes, similar to the ones that have recently become popular in the U.S.:

(1) Last winter it was so cold that I saw my lawyer walking the street with his hands in his own pockets. (1996)

(2) What would you call a thousand lawyers on the bottom of the ocean?

A good start. (1997)

(3) What do a lawyer and a spermatozoid have in common?

Both have a chance of one in a hundred million to become a human being. (2000?)

(4) "You are a very expensive lawyer. If I pay you 500 dollars, would you answer two questions for me?"

"Certainly, what's your second question?" (2001)

(5) Lawyer: "Your honor, I would like to revise my client's case on the basis of new evidence."

Judge: "What evidence would that be?"

Lawyer: "I have discovered that my client still has 500 euro left." (2003)

One joke deals with the lawyer's lack of compassion (3), and one joke wishes lawyers to be dead (2). Three out of five jokes deal with the theme of greed, i.e., (1), (4), (5). In the American jokes, lawyers are depicted as money-grubbing sharks and vultures, as ambulance chasers, as frauds, and as heartless liars. After they die, they go to hell-there are no lawyers in heaven (Moser-Rath 1977: 115-116). Furthermore, they are said to be stupid, lazy, filthy, and even criminal lowlife preferred dead rathe than alive. In Dutch joke telling, these last qualifications are reserved for our neighbors the Belgians (being stupid) and for ethnic minorities like the Surinamese, the Turks, and the Moroccans (being everything else $)^{10}$ - not for lawyers. Finally, a few American lawyer jokes are told in the Netherlands about consultants and accountants.

Here is one example of the latter, sent to me by Anouk Siegenbeek van Heukelom on April 16, 2002:

A farmer is standing in his meadow of sheep, when a car drives up his property. A man steps out of the car and walks up to the farmer.
"Hello, my good man," the driver says; "if I can say within ten minutes how many sheep there are in this meadow, can I then take along one of your sheep?" The farmer takes a look at the man and says it's fine by him, because he doesn't believe the man will succeed.

The man steps intồ his car again, turns on his laptop and logs into a satellite over the meadow. He takes an aerial picture and runs a program to calculate how many sheep there are in the meadow. Seven minutes later, the man walks back to the farmer with the answer: "My good man, there are exactly 485 sheep in your meadow."

In utter amazement the farmer confirms that this is the right answer and that the man can pick a sheep.

After the man has put his reward in his car the farmer says. "Now that you have mber of sheep, I would like to ask you something. If I guess what your profession is, can I then have my animal back?"

The man is slightly puzzled, but he agrees to the proposal of the farmer. "Well," the farmer says: "you are a consultant!"

"Yes, that's right," the man says: "but how can you tell?"

"Well," the farmer explains: "first of all you come here uninvited. Secondly you advise me on subjects I already know (it would be a shame if I didn't know how many sheep I have): Finally you don't know what you are talking about, because you just put my dog into your car!"

The same story is told in the U.S., but there the consultant is a lawyer most of the time.

To my knowledge, no recent increase can be found in lawyer jokes, neither in the Low Countries, nor in Western Europe. In this respect, the sharp increase of lawyer jokes in the U.S. in the 1980s and 1990s is remarkable. ${ }^{11}$ This boom calls for an explanation. Fact is that the Dutch are not reluctant at all to appropriate American narratives. We took over

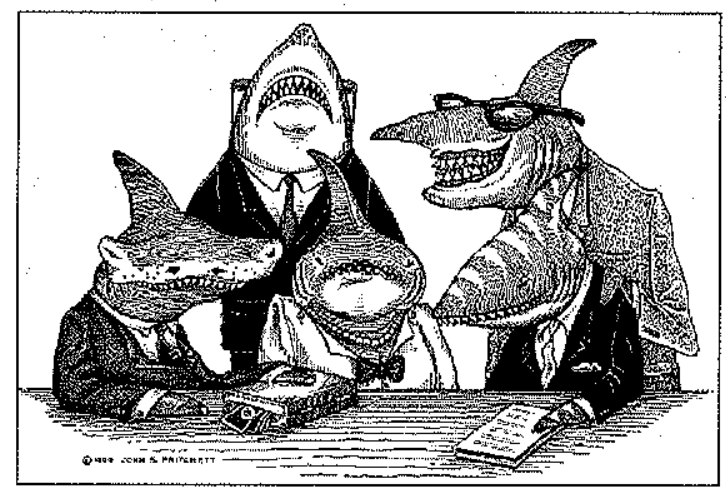

Figure 5. American lawyers as sharks 
the American dumb blond jokes without hesitation. Both American and ar groups of women as stupid and sexually overactive. Along with these jokes, some anti-feminist jokes were added in the Netherlands and Belgium, probably to match men's fears of female emancipation. Most American urban legends found their way to Western Europe as well -- except for some specific university horror stories - probably because of a lack of campus culture in the Netherlands. Apparently there is a breeding ground for lawyer jokes in America, whereas there is none in the Netherlands (yet). There are of course some obvious differences between the American and the Dutch legal system. In ocent dears, the Ameican suing culture is becoming more evident thar of ever. It seems to me that the quantity of lawyer jokes equals the rise of the number and the social status of lawyers, the excessive wages of toplawyers and their sky-high compensation claims. Regarding this last point, I would just like to mention the American lawsuits against tobacco companies and the McDonald's Coffee Case. ${ }^{12}$

From the point of view of ordinary folk, a lawsuit can easily turn into a 'lose-lose' situation. If you lose a case, a claim can bankrupt you. If you win a case, your lawyer's salary can bankrupt you. Remember that most jokes are told from an underdog position-most narrators of jokes are lower and lower-middle class men (Kuipers 2001).

Furthermore, I would like to return to the unpredictable outcome of jurisdiction, although this was a topic in folktales in the past as well. For ordinary folk, the result of a trial cannot be predicted any more on the basis of common sense and a basic sense of justice only. In the opinion of the ordinary citizen, jurisdiction is no longer a matter of finding the truth and doing justice, but a lucrative game in which the most cunning lawyer with the best tricks and the gift of rhetoric wins--especially in the U.S. In other cases, social and ethnic politics prevail over justice, as seems to have happened in the cases of Rodney King and O. J. Simpson. In general, one should not underestimate the role of the news media covering spectacular lawsuits; apart from personal experience and story telling, legal news coverage plays an important role in how ordinary folk look upon justice and lawyers.

\section{Cultural analysis}

Folk narrative research provides a tool for social and cultural analysis. When all of a sudden folktales start focusing on certain groups or

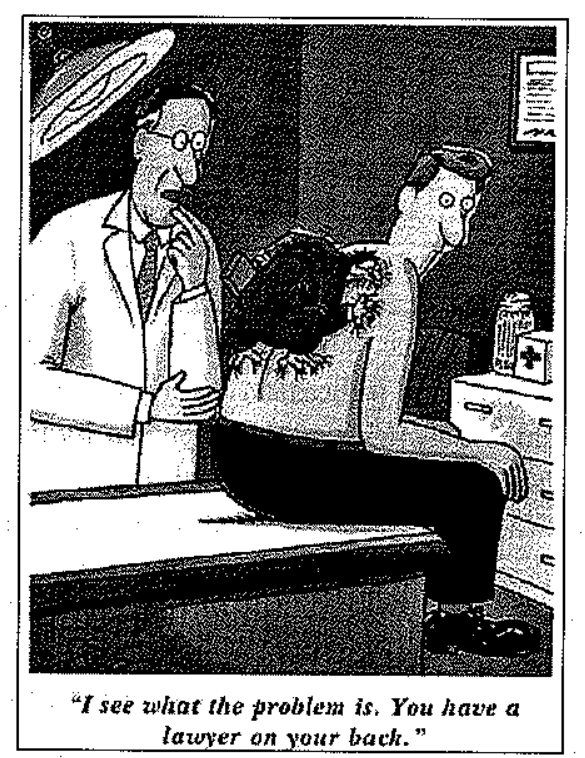

Figure 6. American cartoon by Collins

developments in society, the researcher can be sure there is something brewing. Considering the new jokes and urban legends about Muslims these past few years, we can conclude that people in the Netherlands (and in Western society) have become increasingly worried about the consequences of the armed conflict in the Middle East: especially about the growing number of Muslim fundamentalists in Dutch society, their threats, and their (preparations for) acts of terrorism (like the assassination of Theo van Gogh). Distinct feelings of division between "us" and "them" have manifested themselves as much in real life ${ }^{13}$ as in storytelling and joking.

The fact that American society has become highly legalized cannot be the sole explanation for the sharp increase in lawyer jokes. Highly legalized countries can be found in. Western Europe as well: Great Britain, Germany, and the Netherlands. Folktales in the U.S. indicate that there are distinct feelings of discomfort towards jurisdiction and the legal profession-feelings of discomfort that should be a cause for concern for the judiciary and the lawyers. There are feelings of discontent about the impenetrable logic of justice, but above all the dominant "vulture culture" of suing, claiming, and cashing, as exposed in the news media. This may eventually result in a basic loss of trust in the legal system. 
Remember the underground humor that was a prelude to the fall of communism in the former USSR. Still, this would be a worst-case scenario. Stories need not be dangerous, but they certainly are seldom harmless or meaningless, for stories are often vehicles of latent beliefs, moods, and opinions. What is more, the telling of tales and jokes cannot be suppressed or prohibited.

It is perhaps a comforting thought that in the Netherlands, according to the folktale repertoire, these alarming feelings do not exist to the same extent. Not yet, although one indication of change might be the growing demand for public safety, security, and protection by the government and the law in the Netherlands recently: this might allow Dutch lawyers to gain more influence (and raise their wages) in the near future.

In 1999, there was a Dutch TV-commercial for an insurance company, showing an underage boy joyriding in his father's Saab. Unfortunately, the driver just touches the bumper of a Jaguar standing still in front of a red traffic light. The boy is relieved to see that there is hardly any damage until two Dutch top-lawyers from the Moszkowitz family step out of the Jaguar, one of them feigning whiplash. In the Netherlands, the Moszkowitzes come close to American style lawyers. They have a reputation for having earned their wealth through the winning of big legal cases, so the message of the commercial is that the father of the joyriding boy better be insured, not in the least for legal assistance.

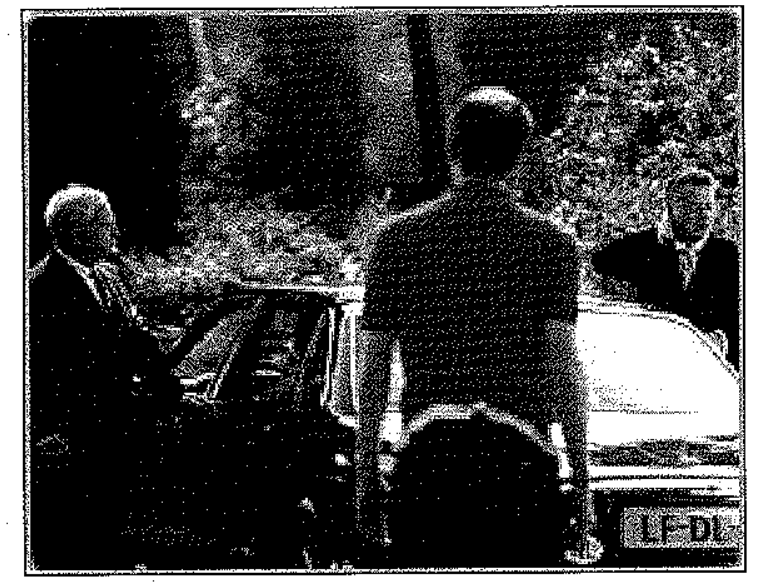

Figure 7. Dutch commercial for insurance company Centraal Beheer: the top-lawyer simulaing whiplash
Perhaps the Dutch should learn from the American situation, because as soon as our lawyers take over the American mores and wages, the news items, the feelings of discontent and the matching folktales will follow automatically. Many hundreds of lawyer jokes already exist in English; unless they are based on English wordplay or verse (for instance: "Between grand theft and a legal fee / There only stands a law degree"), translating them all into Dutch will be as easy as taking candy from a baby.

Meertens Instituut, Amsterdam

\section{Notes}

Correspondence address: Theo.Meder@Meertens.knaw.nt

1. The fairy tale genre of the neck-riddle will be left out. For a dissertation on this subject, see Elias (1998).

2. Jaarsma Collection, report 619, tale no. 1 (archive and Folktale Database, Meerens Instituut, Amsterdam. For my Dutch Folktale Database, see http://www. verhalenbank.nl).

3. One of the best-known versions is "The Friar's Tale" in Geoffrey Chaucer's Canterbury Tales (fourteenth century) (see Benson 1987: 122-128).

. In the tradition of the Schimpff und Ernst-version by Johannes Pauli, see Bolte (1924: 277ff.) and Röhrich (1977: 119-120).

5. Named after the first Dutch book on contemporary legends called Broodje Aap by Ethel Portnoy, published in 1978 (see Portnoy 1992).

6. For published versions, see for instance Wouters (1991: 39-40), Burger (1993: 132-133, 1995: 111). See my Dutch Folktale Database as well: http://www.verhalenbank.nl. 7. See, for instance, Brunvand (1981: 62-65, 1986: 215-216, 1994: 241, 2000: 43-47)

8. See also Moser-Rath (1977: esp. 115): "Die Gesetze entsprachen nicht immer dem Rechtsempinden des gemeinen Mannes; ihre oft unterschiediche und widersprüchlich erliche Sprache der Juristen und die hohen Koute jeglicher Rechtshandlung ließen den Advokat [ ] zur zwielichtionerativen Fisur werden" The first version was told by Geske Kobus-Van der Zee

(Jaarsma Collection, report 50, tale 4; archive of the Meertens Instituut). Other versions can be found in Burger (1995: 30) and Poortinga (1979: 277-278). The story was published by the Brothers Grimm in the first edition of their Kinder- und Hausmärchen (1812; see Rölleke 1986: 1, 101-102), but they left it out in later editions as unsuitable for children. The second version was taken down by Cohen (1919: 254-256). By the way, ATU 1343* is known at least since the Middle Ages; see Spengler (1977: 626-627) and Richter (1993).

10. On this subject, see Kuipers (1995, 1997, 1998, 2000).

11. See Galanter (2005). When I checked in 2006, quite a few of the American websites with many hundreds of lawyer jokes had disappeared. Still to be found on the internet are: 
http://www.scroom.com/SCROOMtimes/Humor/Lawyer.shtml http://xar.us/funny/lawyer.html

Some of the new ones are:

http://www.lawyer-jokes.us/

http://www.ahajokes.com/lawyer_jokes.html

http://paul.merton.ox.ac.uk/work/lawyer-jokes.htm

http://www.workjoke.com/projoke40.htm

http://www.power-of-attorneys.com/joke_categories.asp.

12. See "Want to be a billionaire? Sue a tobacco company," http://www.calahouston.org/ billion.html on the Cikzns Against Lawsit Abuse website. For the McDonald's case,

now from a stricly legal pes: A Groen and L Nicolasen: "Nederlander ziet moslim niet

13. See Kanne (2004). See alo. J. Groen and L. Groen: "Moslim schrikt van slecht imago bij autochtonen," in: De Volkskrant, June 28, 2004; "Bang voor moslims," in: $D$ Volkskrant, June 28, 2004: J. Groen: "Iedereen ziet ons toch als fundamentalist," in: De Volkskrant, June 28, 2004.

\section{References}

Benson, L. D.

1987 The Riverside Chaucer, 3rd ed. Oxford: Oxford University Press.

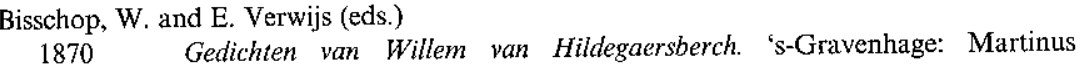
Nijhoff.

Bolte, J. (ed.)

1924 J. Pauli: Schimpff und Ernst. Berlin: Herbert Stubenrauch.

Brunvand, Jan Harlold

1981 The Vanishing Hitchhiker. New York: W.W. Norton and Company.

1986 The Choking Doberman. New York: W.W. Norton and Company.

1994 The Baby Train. New York: W.W. Norton and Company.

2000 The Truth Never Stands in the Way of a Good Story. Chicago: University of Illinois Press.

Burger, Peter

1993 De wraak van de kangoeroe. Amsterdam: Prometheus.

1995 De gebraden baby. Amsterdam: Prometheus.

Cohen, Josef

1919

1998

Nederlandsche Sagen en Legenden II. Zutphen: Thieme.

Galanter, Ma

2005 Rechterraadsels of De twee gezichten van de zondebok. Maastricht: Shaker.

Kanne, $P$. Lowering the
Wisconsin Press.

2004 Giselinde

Gevoelens van autochtone Nederlanders t.o.v. allochtonen and moslims. AmKuipers, Giselinde dam: TNS NIPO.

Etnische humor; Een onderzoek naar de serieusheid van kwetsende grappen. Unpublished manuscript.
Marzolph, Ulric 2001 Meder, Theo

1991

1997

Sprookspreker in Holland. Leven en werk van Willem van Hildegaersberch Ondank is 's werelds loon. In Dekker, T., J. Van der Kooi, and T. Meder (eds.), Van Aladdin tot Zwaan Kleef Aan. Lexicon van sprookjes: ontstaan ontwikkeling, variaties. Nijmegen: Sun, 266-272.

Meder, Theo and E. Venbrux

2000 Vertelcultuur. In Dekker, T., H. Roodenburg, and G. Rooijakkers (eds.), Volkscultuur. Een inleiding in de Nederlandse etnologie. Nijmegen: Sun, 282-336.

Moser-Rath, E.

1977 Advokat. Enzyklopädie des Märchens 1, 115-118.

Pleister, Wolfgang
1988 Menschenrecht, Tierfabel und Tierphysiognomik. In Pleister, W. and W. Schild (eds.), Recht und Gerechtigkeit im Spiegel der europäischen Kunst. Schild (eds.), Recht und Gereche:

Poortinga, Ype
1979

De foet fan de reinbôge. Fryske folksferhalen. Baarn: Bosch and Keuning Portnoy, Ethel

1992 [1978] Broodje Aap. De folklore van de post-industriële samenleving, 10th ed. Amsterdam: Uitgeverij De Harmonie.

Richter, Dieter

1993 Kinder spielen Schweineschlachten. Enzyklopädie des Märchens 7, 1264 1267.

Röhrich, L.

1977 Advokat und Teufel. Enzyklopädie des Märchens 1, 118-123.

Rölleke, $\mathrm{H}$

986 Kinder- und Hausmärchen, gesammelt durch die Brüder Grimm. Göttingen: Vandenhoeck \& Ruprecht.

Spengler, W. Eckehart

1977 Apfelprobe. Enzyklopädie des Märchens 1, 626-628.

1969 Index Exemplorum. A Handbook of Medieval Religious Tales. Helsinki: Suomalainen Tiedeakatemia, FFC 204

Hans-Jörg.

2004 Types of International Folktales. A Classification and Bibliography, Based on the System of Antti Aarne and Stith Thompson. Helsinki: Suomalainen Tie deakatemia, FFC, 284-286. 
454 T. Meder

Van der Kooi, Jurjen

1997 Deurwaarder en duivel. In Dekker, T., J. Van der Kooi, and T. Meder (eds.), Van Alaken Zwaan Klaf Aan. Lexicon van sprookjest on

Vries, Jan de wikkeling, variaties. Nijmegen: Sun, 88-90. sinki: Suomalainen Tiedeakatemia, FFC 73.

1991 